XANTAÇÃO DE RESíDUOS DE SAWDUST PARA ADSORÇÃO DE ÍONS DE CHUMBO A PARTIR DE SOLUÇÕES AQUOSAS

\title{
XANTHATION OF SAWDUST WASTE FOR ADSORPTION OF LEAD IONS FROM AQUEOUS SOLUTIONS
}

\author{
NUÑEZ-HERNANDEZ, Jaider Enrique; COLPAS-CASTILLO, Fredy; FERNANDEZ-MAESTRE, \\ Roberto* \\ Universidad de Cartagena; Campus de San Pablo, Facultad de Ciencias Exactas y Naturales, Programa de \\ Quimica, Cartagena, Colombia (tel. +575-6469578 fax +575-6698180) \\ * Corresponding author \\ e-mail: rfernandez@unicartagena.edu.co
}

Received 12 August 2016; received in revised form 28 September 2016; accepted 07 December 2016

\section{RESUMO}

Metais pesados em efluentes industriais tenham contaminado águas naturais comprometendo a saúde dos seres humanos e animais. Os métodos tradicionais eliminam estes metais de águas residuais, mas eles são dispendiosos ou ineficaz em baixas concentrações de metais para os quais são necessários métodos alternativos. Nós investigamos a absorção de chumbo na serragem xanthated (tratamento $\mathrm{CS}_{2}$ ). testes de cinética e de $\mathrm{pH}$, isotérmicas de adsorção e espectroscopia de infravermelho foram realizadas. Estudos cinéticos indicaram que a adsorção equilibrada a 120 minutos a seguir uma cinética de pseudo-segunda ordem. A capacidade de adsorção foi de $72 \mathrm{mg} \mathrm{Pb}^{2+} \mathrm{g}^{-1}$ (máxima em $\mathrm{pH}$ 5, Freundlich tipo isotérmica, 98\% de adsorção). Este produto obtido de matérias-primas sem valor comercial, pode ser usado para recuperação ambiental como alternativa ao dumping sua caros em aterros sanitários.

Palavras-chave: Estudos cinéticos; metais pesados; trocador catiônico; curva isotérmica

\begin{abstract}
Heavy metals in industrial effluents have contaminated natural waters compromising the health of humans and animals. Traditional methods eliminate these metals from wastewater but they are costly or ineffective at low metal concentrations for which alternative methods are required. We investigated the adsorption of lead on xanthated sawdust ( $\mathrm{CS}_{2}$ treatment). Kinetic and $\mathrm{pH}$ tests, adsorption isotherms and infrared spectroscopy were performed. Kinetic studies indicated that adsorption equilibrated at 120 min following a kinetic model of pseudo-second order. The adsorption capacity was $72 \mathrm{mg} \mathrm{Pb}^{2+} \mathrm{g}^{-1}$ (maximum at $\mathrm{pH}$ 5, Freundlich type isotherm, $98 \%$ adsorption). This product obtained from raw materials without commercial value, can be used for environmental remediation as an alternative to its expensive dumping into landfills.
\end{abstract}

Keywords: Kinetic studies; contamination; heavy metals; cation exchanger; isotherm

PERIÓDICO TCHÊ QUÍMICA • www.periodico.tchequimica.com • Vol. 14 N. 27.

• ISSN 1806-0374 (impresso) • ISSN 1806-9827 (CD-ROM) • ISSN 2179-0302 (meio eletrônico)

(C) 2017. Porto Alegre, RS. Brasil 


\section{INTRODUCTION}

The disposal of heavy metals through industrial effluents has led to contamination of natural water bodies. This has endangered the health of humans and animals because, as metals are not biodegradable, they can accumulate in living tissues causing various diseases and disorders by their toxic and carcinogenic effects (Ngah and Hanafiah, 2008). To remove heavy metals from wastewater, various conventional methods have been used; however, these methods are not economical or effective when metal concentration is in the $1-100 \mathrm{mg} \mathrm{L}^{-1}$ range (Torres-Blancas et al., 2013). Different biomass residues, such as orange peels (Liang et al., 2009), de-oiled allspice husk (Torres-Blancas et al., 2013), and other biomass types (Patriota et al. 2016) have been used as bioadsorbents for the removal of heavy metals in wastewater. Carboxylic and phenolic groups are the main active sites for metal removal onto native agricultural waste (Pagnanelli et al., 2003).

Adsorbents are chemically modified by addition of different chelating groups to increase their adsorption capacity. Sulfur groups as sulfides, thiols, dithiocarbamates, dithiophosphates and xanthates have also been used to increase the adsorption capacity of agricultural waste (Torres-Blancas et al., 2013; Liang et al., 2009; Chakraborty and Tare, 2006; Kumar et al., 2000; Pillai et al., 2013). These groups are characterized by a high affinity for heavy metals but a low affinity for the light ones. Xanthates are formed by reacting an organic substrate containing hydroxyl groups, with carbon disulfide under basic conditions according to equation 1 (Liang et al., 2009):

Sawdust is mainly composed of cellulose, hemicellulose and lignin, and is an ideal substrate for the synthesis of xanthates due to its high content of hydroxyl functional groups. In this study, we prepared an adsorbent by incorporation of xanthate groups to the sawdust surface and evaluated its capacity to adsorb $\mathrm{Pb}^{2+}$ from aqueous solutions through adsorption, kinetic and optimum adsorption $\mathrm{pH}$ studies.

\section{METHODOLOGY}

\subsection{Instrumental}

Metal concentrations were determined by flame atomic absorption spectrometry (ICE 3000, Thermo Scientific, Zeeman correction). Other parameters were measuring time: $4.0 \mathrm{~s}$ and number of replicate analyses, 3 . Solutions were prepared with a sodium acetate/acetic acid buffer and the ionic strength was adjusted with $\mathrm{NaCl}$. Infrared spectra of the adsorbents were obtained by mixing one mg of sample with $100 \mathrm{mg}$ of $\mathrm{KBr}$, compressing to obtain a pellet that was analyzed on a FTIR (SHIMADZU-8400) in the $4000-400 \mathrm{~cm}^{-1}$ range, to identify the functional groups involved in the adsorption of heavy metals.

\subsection{Xanthation of Sawdust}

Carito wood sawdust (Enterolobium cyclocarpum) was obtained from a local sawmill (Cartagena, Colombia), washed with distilled water and dried at $70^{\circ} \mathrm{C}$ for $24 \mathrm{~h}$. Subsequently, it was milled in a ball mill, sieved to a $0.225 \mathrm{~mm}$ particle size, washed with $0.1 \mathrm{~N} \mathrm{HCl}$ and distilled water to neutral $\mathrm{pH}$; then, it was dried at $70^{\circ} \mathrm{C}$ for $24 \mathrm{~h}$ to remove colored substances and contaminants. The product obtained was named S. Later, xanthation was performed according to equation 1: twenty five grams of sawdust were put in a polyethylene vial mechanically stirred, $500 \mathrm{ml}$ of a $4 \mathrm{M} \mathrm{NaOH}$ solution were added using a 0.33 sawdust $/ \mathrm{NaOH}$ w/w ratio stirring for 3 hours and, finally, $30 \mathrm{ml}$ of $\mathrm{CS}_{2}$ with a $1.12 \mathrm{CS}_{2} / \mathrm{sawdust} \mathrm{w} / \mathrm{w}$ ratio stirring for 4 hours. The mixture was allowed to stand for 16 hours, filtered, washed several times with deionized water and dried at $70^{\circ} \mathrm{C}$ (Chakraborty and Tare, 2006). This product was named XS.

$$
\mathrm{R}-\mathrm{OH}+\mathrm{CS}_{2}+\mathrm{NaOH} \rightarrow \mathrm{R}-\mathrm{OCS}_{2} \mathrm{Na}
$$

\subsection{Effect of $\mathrm{pH}$}

The effect of $\mathrm{pH}$ on $\mathrm{Pb}^{2+}$ adsorption was examined by mixing $50 \mathrm{mg}$ of XS or $\mathrm{S}$ with $10 \mathrm{ml}$ of $100 \mathrm{ppm}$ of $\mathrm{Pb}^{2+}$ at $25^{\circ} \mathrm{C}$ at $\mathrm{pH}$ values of 3 to 5 adjusted by adding $0.1 \mathrm{M} \mathrm{HNO}_{3}$ and $0.1 \mathrm{M} \mathrm{NaOH}$ solution. After $3 \mathrm{~h}$ stirring, the solutions were filtered and $\mathrm{Pb}^{2+}$ was determined in the filtrate.

\subsection{Kinetic Study and Adsorption Experiments}

$500 \mathrm{mg}$ of adsorbent were mixed with 100 $\mathrm{ml}$ of $100 \mathrm{ppm}$ of $\mathrm{Pb}^{2+}$ at $\mathrm{pH} 5$ for $2.2 \mathrm{~h}$ and $25^{\circ}$ C. Samples were extracted at different time inter-

PERIÓDICO TCHÊ QUÍMICA • www.periodico.tchequimica.com • Vol. 14 N. 27 - ISSN 1806-0374 (impresso) • ISSN 1806-9827 (CD-ROM) • ISSN 2179-0302 (meio eletrônico) 
vals, and filtered to determine their concentrations. In the adsorption experiments, $50 \mathrm{mg}$ of adsorbent were mixed with $10 \mathrm{ml}$ of $25,50,100,200$ or $400 \mathrm{ppm}$ of $\mathrm{Pb}^{2+}$ at $\mathrm{pH} 5$ for $2 \mathrm{~h}$ and $25^{\circ} \mathrm{C}$. The amount of adsorbed metal, $\mathrm{q}_{\mathrm{e}}$, was determined using:

$$
q_{e}=\frac{\mathrm{C}_{0} \mathrm{~V}_{0}-\mathrm{C}_{\mathrm{e}} \mathrm{V}_{0}}{\mathrm{~m}}(E q .2)
$$

Where $C_{0}$ is the initial concentration of $\mathrm{Pb}^{2+}$ in $\mathrm{mg} \mathrm{L}^{-1}, \mathrm{~V}_{0}$ the initial volume in liters, $\mathrm{C}_{\mathrm{e}}$ the equilibrium concentration of $\mathrm{Pb}^{2+}$ in $\mathrm{mg} \mathrm{L}^{-1}$ and $\mathrm{m}$ the mass of adsorbent in grams.

\section{RESULTS AND DISCUSSION}

\section{$3.1 \mathrm{pH}$ Effect}

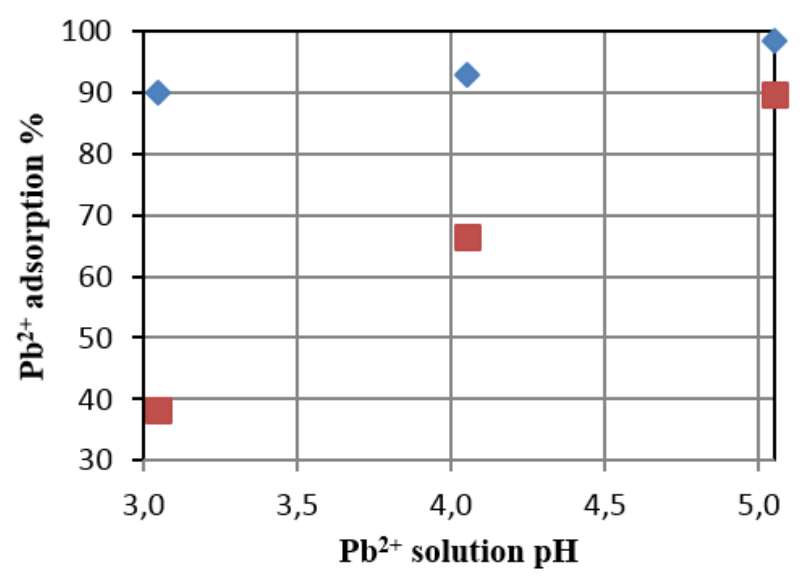

Figure 1. Effect of the exchange solution $\mathrm{pH}$ on $\mathrm{Pb}^{2+}$ adsorption on $\mathrm{S}(\mathbf{\square})$ and $X S(\$)$. Adsorbent dose: $50 \mathrm{mg} / 10 \mathrm{ml}$, concentration: $100 \mathrm{ppm}$ of $\mathrm{Pb}^{2+}$, contact time: $3 \mathrm{~h}$. The optimum adsorption pH was 5.

$\mathrm{pH}$ affects $\mathrm{Pb}^{2+}$ adsorption from aqueous solutions on $\mathrm{S}$ and $\mathrm{XS}$ (Figure 1). $\mathrm{A}$ poor $\mathrm{Pb}^{2+}$ adsorption was observed at acid $\mathrm{pH}$ because of strong electrostatic repulsion between $\mathrm{H}^{+}$and metal ions on the sawdust surface, preventing metal ions from interacting with the adsorbent (Jiang et al., 2009). This type of competition has been described with metal biosorption onto olive pomace waste (Pagnanelli et al., 2003). The greater adsorption at lower $\mathrm{pH}$ for $\mathrm{XS}$ than for $\mathrm{S}$ was due to the higher nucleophilicity of xanthate groups than that of the original oxygen groups in $\mathrm{S}$; therefore, even at low $\mathrm{pH}, \mathrm{XS}$ showed a high adsorption of $\mathrm{Pb}^{2+}$. By increasing $\mathrm{pH}$, the repulsion force becomes weak favoring $\mathrm{Pb}^{2+}$ diffusion to the adsorbent surface, increasing adsorption (Acar and Eren, 2006). Figure 1 shows that the maximum adsorption on $\mathrm{S}$ and $\mathrm{XS}$ was obtained at $\mathrm{pH} 5$ with adsorptions of $89 \%$ and $98 \%$ of $\mathrm{Pb}^{2+}$ from $100 \mathrm{ppm}$ solutions and $50 \mathrm{mg} / 10 \mathrm{ml}$ doses of adsorbent, respectively. The main advantage of $\mathrm{XS}$ over $\mathrm{S}$ was that $\mathrm{Pb}^{2+}$ adsorption was higher for $\mathrm{XS}$ at all $\mathrm{pH}$ values, especially at low $\mathrm{pH}$. This is consistent with Torres-Blancas et al. (2013) who evaluated the adsorption of lead on pepper peel and xanthated pepper peel. They observed that at acid $\mathrm{pH}$, adsorption on pepper peel was poor as a result of the strong electrostatic repulsion, while the adsorption of lead was high at all $\mathrm{pH}$ for XS; similar results were obtained by Liang et al. (2009) and Taty-Costodes et al. (2003)

\subsection{Adsorption Kinetics}

One important property of adsorbents is the speed with which the adsorbate is adsorbed and reaches equilibrium. The mathematical model that describes the amount of $\mathrm{Pb}^{2+}$ adsorbed at a zero time and at a specific time, is given by:

$$
\left(\frac{m g \mathrm{~Pb}^{2+}}{\mathrm{g}}\right)_{\mathrm{n}}=\frac{\left[(\mathrm{CV})_{\mathrm{n}-1}-(\mathrm{CV})_{\mathrm{n}}\right]}{\mathrm{g}}+\left(\frac{\mathrm{mg} \mathrm{Pb}{ }^{2+}}{\mathrm{g}}\right)_{\mathrm{n}-1}
$$

Where $C$ is the remaining concentration of $\mathrm{Pb}^{2+}$ at time $\mathrm{t}$ in $\mathrm{mg} \mathrm{L}^{-1}$ (calculated with Equation 2 ), $V$ the volume of the remaining solution at time $t$ in liters, and $n$ the number of data taken in time t. Using the graph of $\mathrm{Pb}^{2+}$ adsorbed as a function of time, we identified the time the equilibrium was reached and the corresponding adsorption capacity, $\mathrm{q}_{\mathrm{e}}$ (Silgado et al., 2014). To assess the rate of $\mathrm{Pb}^{2+}$ adsorption on $\mathrm{S}$ and $\mathrm{XS}$, two kinetic models were considered. The model of pseudofirst order was proposed by Lagergren (Tseng et al., 2010; Lagergren, 1898):

$$
\log \left(\mathrm{q}_{\mathrm{e}}-\mathrm{q}_{\mathrm{t}}\right)=\log \mathrm{q}_{\mathrm{e}}-\frac{\mathrm{k}_{1}}{2.303} \mathrm{t}
$$

Where $q_{e}$ and $q_{t}$ are the adsorption capacities $\left(\mathrm{mg} \mathrm{g}^{-1}\right)$ at equilibrium and time $\mathrm{t}$, respectively, and $\mathrm{k}_{1}$ is the rate constant model $\left(\mathrm{min}^{-1}\right)$. $\mathrm{k}_{1}$ values were obtained from the intercept and 
slope of the graph of $\log \left(q_{e}-q_{t}\right)$ vs. t. The kinetic model of pseudo-second order is given by:

$$
\frac{\mathrm{t}}{\mathrm{q}_{\mathrm{t}}}=\frac{1}{\mathrm{k}_{2} \mathrm{q}_{\mathrm{e}}^{2}}+\frac{1}{\mathrm{q}_{\mathrm{e}}} t
$$

Where $q_{e}$ and $q_{t}$ were defined in the model of pseudo-first order, and $k_{2}$ is the rate constant model of pseudo-second order $\left(\mathrm{g} \mathrm{mg}^{-1} \mathrm{~min}^{-1}\right)$ (Torres-Blancas et al., 2013). $\mathrm{k}_{2}$ and $\mathrm{q}_{\mathrm{e}}$ values were obtained from the intercept and slope of the graph of $t / q_{t}$ vs. $t$ (Silgado et al., 2014). The fact that $S$ and SX fit a pseudo-second-order kinetics shows that the limiting-speed step can be caused by chemical sorption or chemisorption involving valence forces through the exchange of electrons between sorbent and sorbate (Ho and McKay, 1999; Ho, 2006). Xanthate groups allow SX to adsorb metal ions by ion exchange or complexation, or a combination of both processes. By ion exchange, two sulfur atoms, negatively charged, capture $\mathrm{Pb}^{2+}$, while complex formation occurs between the sulfur atoms and $\mathrm{Pb}^{2+}$, which is characterized by empty orbitals that can be occupied by the xanthate free electrons to form a complex (Torres 2013). This model also assumes that the initial rate of adsorption, $h_{0},\left(\mathrm{mg} \mathrm{g}^{-1} \mathrm{~min}^{-1}\right)$ is proportional to the square of the number of remaining free surface sites, and is defined by:

$$
h_{0}=k_{2} q_{e}^{2}
$$

Where $\mathrm{q}_{\mathrm{e}}$ and $\mathrm{k}_{2}$ are the adsorption capacity $\left(\mathrm{mg} \mathrm{g}^{-1}\right)$ and the pseudo-second order model rate constant $\left(\mathrm{g} \mathrm{mg}^{-1} \mathrm{~min}^{-1}\right)$, respectively. The results obtained for each model are described in Table 1.

Table 1. Kinetic parameters for $S$ and XS. $\mathrm{Pb}^{2+}$ concentration: $100 \mathrm{ppm}$, adsorbent dose: $500 \mathrm{mg} / 100$

\begin{tabular}{|c|c|c|c|c|c|c|c|c|}
\hline \multirow[b]{3}{*}{ Adsorbent } & \multirow[b]{3}{*}{$\begin{array}{c}q_{e} \\
(\exp )\end{array}$} & \multicolumn{7}{|c|}{ Kinetic Model } \\
\hline & & \multicolumn{3}{|c|}{ Pseudo first order } & \multicolumn{4}{|c|}{ Pseudo second order } \\
\hline & & $\begin{array}{c}q_{e} \\
\text { model } \\
\left(\mathrm{mq} \mathrm{q}^{-1}\right)\end{array}$ & $\begin{array}{c}\mathbf{k}_{1} \\
\mathbf{m i n}^{-1}\end{array}$ & $\mathbf{R}^{2}$ & $\begin{array}{c}q_{e} \\
\text { model } \\
\left(\mathrm{mq} \mathrm{q}^{-1}\right)\end{array}$ & $\begin{array}{c}\mathrm{k}_{2} \\
\left(\mathrm{~g} \mathrm{mg}^{-1}\right. \\
\left.\mathrm{min}^{-1}\right)\end{array}$ & $\mathbf{R}^{2}$ & $h_{0}\left(m g g^{-1}\right)$ \\
\hline $\mathbf{S}$ & 17.8 & 17.0 & 0.045 & 0.972 & 17.6 & 0.047 & 0.999 & 14.8 \\
\hline XS & 19.3 & 16.6 & 0.027 & 0.967 & 19.2 & 0.095 & 0.999 & 35.6 \\
\hline
\end{tabular}
$\mathrm{ml}, \mathrm{pH}$ : 5, contact time: $140 \mathrm{~min}$. Adsorbents $S$ and XS followed a pseudo second-order kinetics.

From the data, it follows that, for the pseudo-first order kinetic model, the theoretical values of $\mathrm{q}_{\mathrm{e}}$ for $\mathrm{S}$ and $\mathrm{XS}$ differ from the experimental $q_{e}$, as evidenced by the regression coefficients of 0.972 and 0.967 for $S$ and XS, respectively, but they agree on the model of pseudosecond order with a regression coefficient of 0.999 for both $S$ and XS. Therefore, the mechanism of adsorption of lead ions on $S$ and $X S$ is represented by the pseudo-second order kinetic model, and this agrees with the (Liang et al., 2011; Liang et al., 2009; Torres-Blancas et al., 2013). This indicates that chemical adsorption was the mechanism of speed control. As for the initial velocity $h_{0}$, this was faster for XS than for $S$, confirming that xanthation increases the adsorbent affinity towards metals.

\subsection{Adsorption Isotherms}

Adsorption isotherms are mathematical models used to estimate the maximum amount of contaminant that an adsorbent can remove from an aqueous solution. The adsorption isotherms were evaluated using the Langmuir and Freundlich models. The Langmuir isotherm is given by:

$$
\frac{C_{e}}{q_{e}}=\frac{1}{q_{m} b}+\frac{C_{e}}{q_{m}}
$$

Where $\mathrm{q}_{e}$ is the amount of material retained by a specific amount of adsorbent $\left(\mathrm{mg} \mathrm{g}^{-1}\right)$, $\mathrm{C}_{\mathrm{e}}$ the equilibrium concentration $\left(\mathrm{mg} \mathrm{L}^{-1}\right), \mathrm{q}_{\mathrm{m}}$ the amount of metal or contaminant necessary to form a monolayer on the adsorbent surface (mg $\mathrm{g}^{-1}$ ) and expresses its maximum adsorption capacity, and $b$ the Langmuir constant $\left(\mathrm{L} \mathrm{mg}^{-1}\right)$ (Silgado et al., 2014; Sciban et al., 2006). The es- 
sential characteristics of the Langmuir isotherm can be expressed in terms of a constant dimension known as the separation factor RL given by:

$$
R L=\frac{1}{1+b C_{0}}
$$

Where, $b$ is the Langmuir constant and $C_{0}$ the initial concentration of adsorbate in the solution. We used RL to obtain the shape of the isotherm and the favorability of adsorption, according to the following criteria: if $\mathrm{RL}>1$ adsorption is unfavorable, $\mathrm{RL}=1$ linear, $0<\mathrm{RL}<1$ favorable, and $\mathrm{RL}=0$ the adsorption is irreversible (Memon et al., 2007).

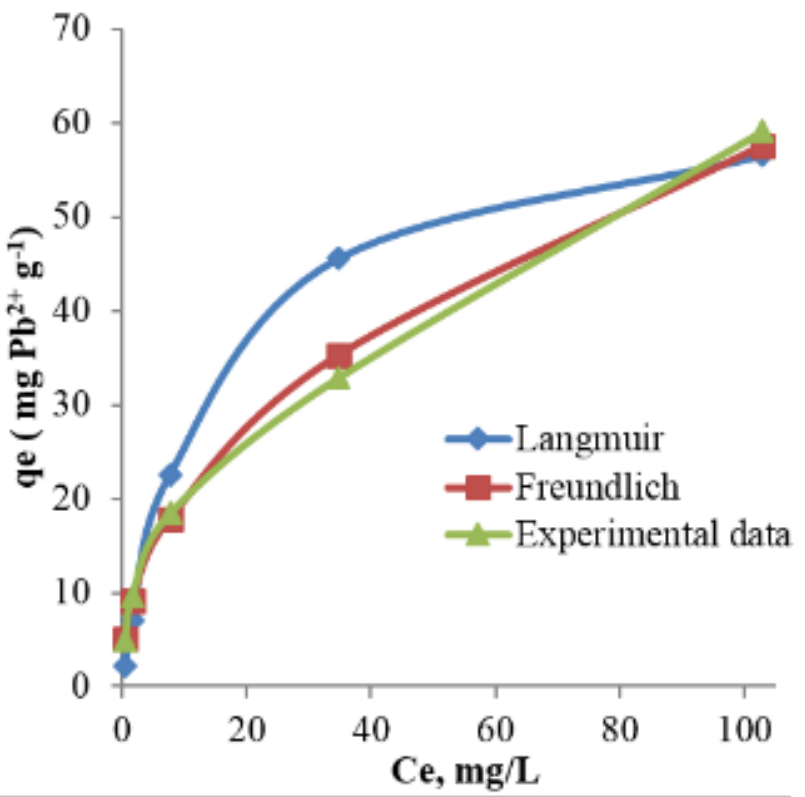

Unlike the Langmuir isotherm, that assumes a homogeneous surface, the Freundlich isotherm considers a heterogeneous surface and is used at low pressures:

$$
\log q_{e}=\log K F+\frac{1}{n} \log C_{0}
$$

Where $q_{e}$ is the amount of material adsorbed by a specific amount of adsorbent (mg g $\left.{ }^{1}\right), C_{e}$ the equilibrium concentration $\left(\mathrm{mg} \mathrm{L}^{-1}\right)$ in the liquid phase, KF the Freundlich constant $\left(\mathrm{mg}^{1 / n}\right.$ $\mathrm{L}^{1 / \mathrm{n}} \mathrm{g}^{-1}$ ) and $\mathrm{n}$ the heterogeneity factor which depends on the substance (Liang et al., 2009). Figure 2 shows the Langmuir and Freundlich isotherms for $\mathrm{Pb}^{2+}$ adsorption and Figure 3 the separation factors for S and XS.

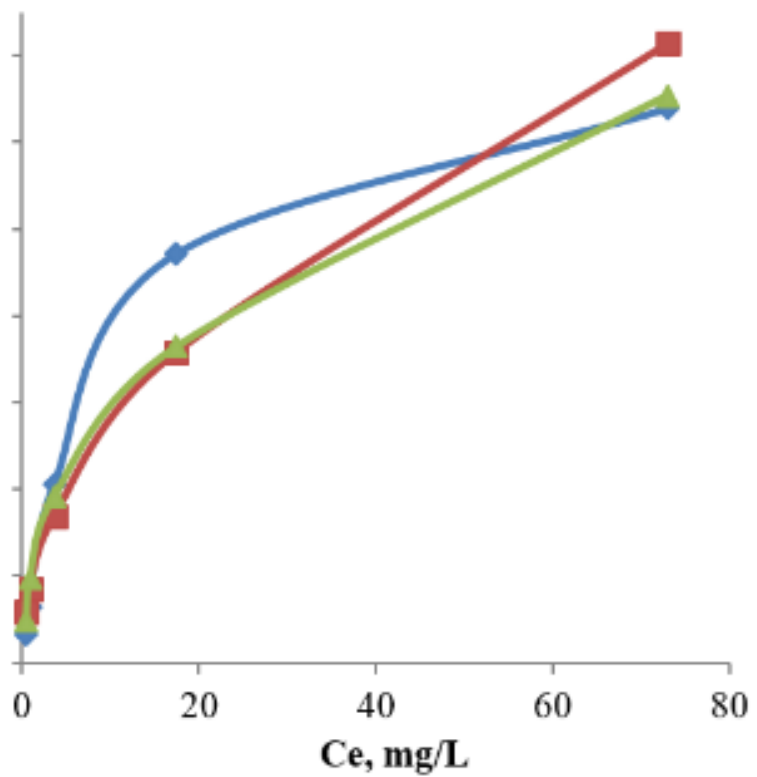

Figure 2. Langmuir and Freundlich isotherms for $\mathrm{Pb}^{2+}$ adsorption on $\mathrm{S}$ (left) and XS (right). Adsorbent dose: $50 \mathrm{mg} / 10 \mathrm{ml}$, metal concentration: $100 \mathrm{ppm}$ of $\mathrm{Pb}^{2+}$, contact time: $120 \mathrm{~min}$. $\mathrm{pH}$ : 5 . Sand XS fit the Freundlich isotherm; $q_{e}$ is the sawdust adsorption capacity of $\mathrm{Pb}^{2+}$ and $\mathrm{C}_{e}$ the equilibrium concentration of $\mathrm{Pb}^{2+}$.

The isotherms in Figure 2 show that the adsorption capacity in the equilibrium, $\mathrm{C}_{\mathrm{e}}$, increases as a function of concentration in solution, $\mathrm{q}_{e}$, while Figure 3 confirms that the adsorption of $\mathrm{Pb}^{2+}$ on $\mathrm{S}$ and XS was favorable because the RL values for all metal concentrations were in the range $0-1$. According to Kumar et al. (2000) this means that adsorption is more favorable at high concentrations. Table 2 shows the values of the isotherm parameters for $S$ and XS, determined by least squares. 
Table 2. Langmuir and Freundlich isotherm parameters for $\mathrm{Pb}^{2+}$ adsorption on $\mathrm{S}$ and $\mathrm{XS}$.

\begin{tabular}{|c|c|c|c|c|c|c|c|}
\hline \multirow[b]{3}{*}{ Adsorbent } & \multicolumn{7}{|c|}{ Kinetic Model } \\
\hline & \multicolumn{4}{|c|}{ Pseudo first order } & \multicolumn{3}{|c|}{ Pseudo second order } \\
\hline & $\begin{array}{c}q_{m} \\
\mathbf{m g ~ g}^{-1}\end{array}$ & $\begin{array}{c}\mathbf{b} \\
\mathrm{L} \mathrm{mg}^{-1}\end{array}$ & $\mathbf{R}^{2}$ & $\mathbf{R L}$ & $\begin{array}{c}\mathbf{K}_{\mathbf{f}} \\
\mathbf{L ~ g}^{-1}\end{array}$ & $\mathrm{n}$ & $\kappa$ \\
\hline $\mathbf{S}$ & 64.5 & 0.069 & 0.938 & 0.062 & 7.04 & 2.20 & 0.997 \\
\hline XS & 72.0 & 0.1109 & 0.977 & 0.115 & 9.02 & 2.07 & 0.981 \\
\hline
\end{tabular}
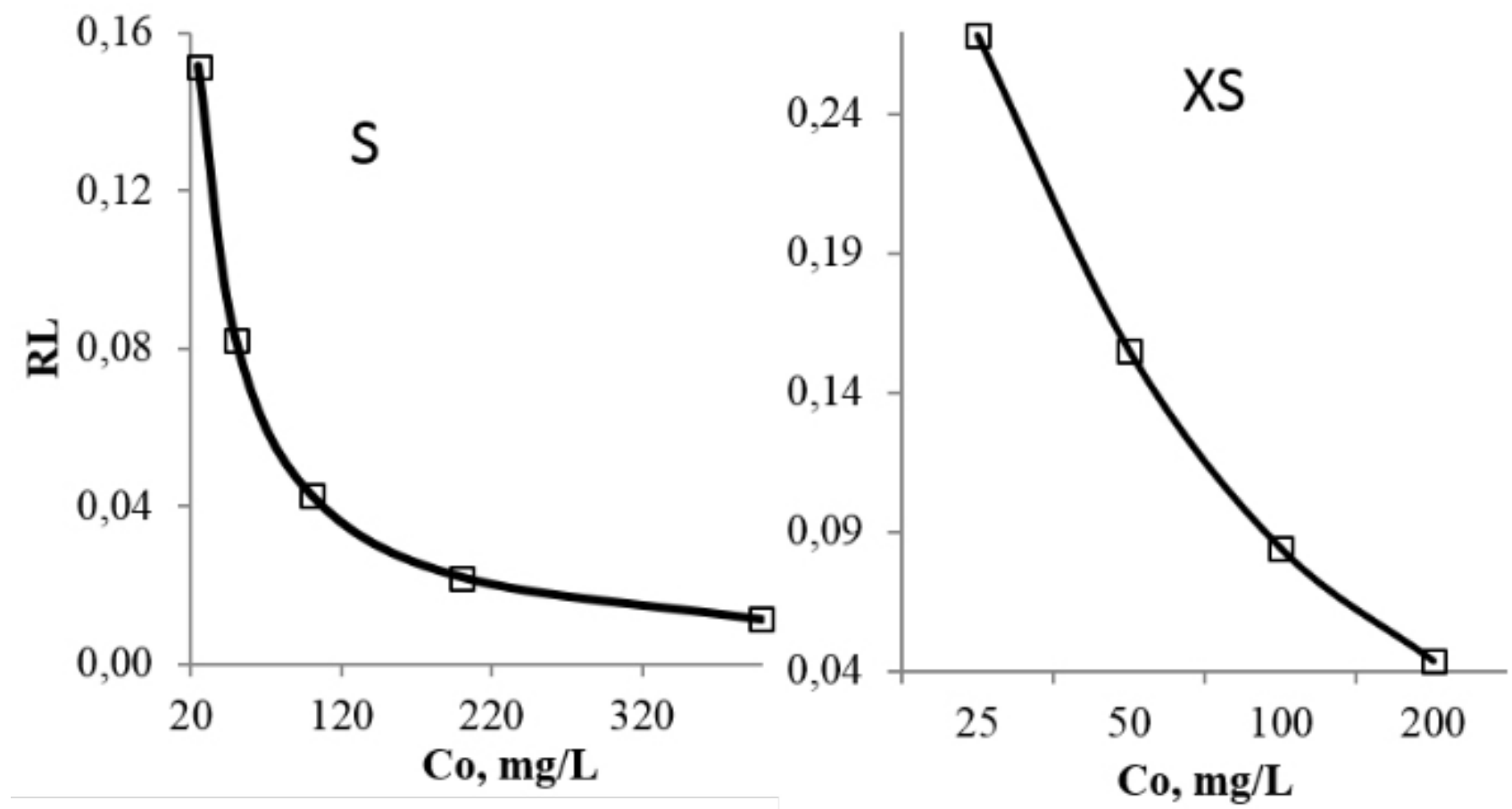

Figure 3. Separation Factors (RL) in the adsorption of $\mathrm{Pb}^{2+}$ on $\mathrm{S}$ (left) and $\mathrm{XS}$ (right). Adsorption was favorable because $0<R L>1 . C_{0}$ is the initial concentration of $\mathrm{Pb}^{2+}$.

To determine which of the two isotherm models was best suited to $\mathrm{Pb}^{2+}$ adsorption, we evaluated correlation coefficients that measure how well the experimental values were adjusted to theoretical ones (Panda et al., 2008). Table 2 shows that the correlation coefficients with respect to lead adsorption on S were 0.938 and 0.977 , and for XS, 0997 and 0981, for the Langmuir and Freundlich models, respectively. This means that, for both adsorbents, the Freundlich model gave the best fit; that is, lead adsorption occurred due to the energy distribution of the active sites for adsorption and the absence of monolayers. These results agree with those reported by Torres-Blancas et al. (2013) who established that the adsorption of lead on xanthated and untreated pepper peel follows a Freundlich isotherm type. Our results also partially agree with Liang et al. (2009) who studied the adsorption of lead on untreated orange peel, and concluded that it follows a Freundlich isotherm type, but once xanthated follows a Langmuir type. This means that the type of adsorption isotherm depends on the nature of adsorbent used.

\subsection{Infrared Spectroscopy Analysis}

The FTIR spectra of $S$ and XS are shown in Figure 4. In the spectrum of $S$, broad, intense absorption peaks around $3442 \mathrm{~cm}^{-1}$ correspond to $\mathrm{OH}$ stretching vibrations due to inter and intra macromolecular hydrogen bonds of molecular associations such as alcohols and phenols (TorresBlancas et al., 2013), and at $2923 \mathrm{~cm}^{-1}$ due to $\mathrm{CH}$ groups stretching vibration produced by alkanes and $-\mathrm{OCH}_{3}-\mathrm{CH}_{2} \mathrm{OH}$ groups, in cellulose and lignin (Liang et al., 2011). The peak at $1739 \mathrm{~cm}^{-1}$ was the result of stretching vibrations of carbonyl groups in lignin. The peaks at 1645, 1514, 1503, 
1463 and $1425 \mathrm{~cm}^{-1}$ are due to stretching vibrations of $\mathrm{C}=\mathrm{C}$ bonds of aromatic groups in lignin. The peaks at 1040, 1050, 1160, 1242 and 1368 $\mathrm{cm}^{-1}$ were assigned to torsion or deformation and $\mathrm{O}-\mathrm{H}$ stretching vibrations of $\mathrm{C}-\mathrm{O}$ of primary and secondary alcohols, and phenolic groups, and that at $667 \mathrm{~cm}^{-1}$ to balancing of $\mathrm{C}-\mathrm{H}$ groups. Some changes were observed in the spectrum of $\mathrm{XS}$ with respect to $\mathrm{S}$. For example, the peaks due to stretching vibrations of $\mathrm{OH}, \mathrm{CH}_{2}$ and $\mathrm{CH}_{3}$ groups were weaker and more elongated than in $S$ because hydroxyl groups reacted with $\mathrm{CS}_{2}$. Xanthate groups in XS were identified by the appearance of new peaks at 612,899 and $1237 \mathrm{~cm}$ 1 that correspond to $\gamma \mathrm{C}-\mathrm{S}, \gamma \mathrm{C}=\mathrm{S}$ and $\gamma \mathrm{S}-\mathrm{C}-\mathrm{S}$ vibrations. This is consistent with reports by Panda et al. (2008) who identified xanthate groups in Lathyrus Sativus peel, a legume from Asia and East Africa, by peaks appearing at 661 and between $1200-1250 \mathrm{~cm}^{-1}$; Pillai et al. (2011) who associated sulfur groups to peaks at 538, 1020 and $1151.5 \mathrm{~cm}^{-1}$ corresponding to $\gamma \mathrm{C}-\mathrm{S}, \gamma \mathrm{C}=\mathrm{S} \mathrm{y}$ $\gamma$ S-C-S vibrations; and Mustafa et al. (2004) who indicated that xanthate groups are found at 800 $1200 \mathrm{~cm}^{-1}$.

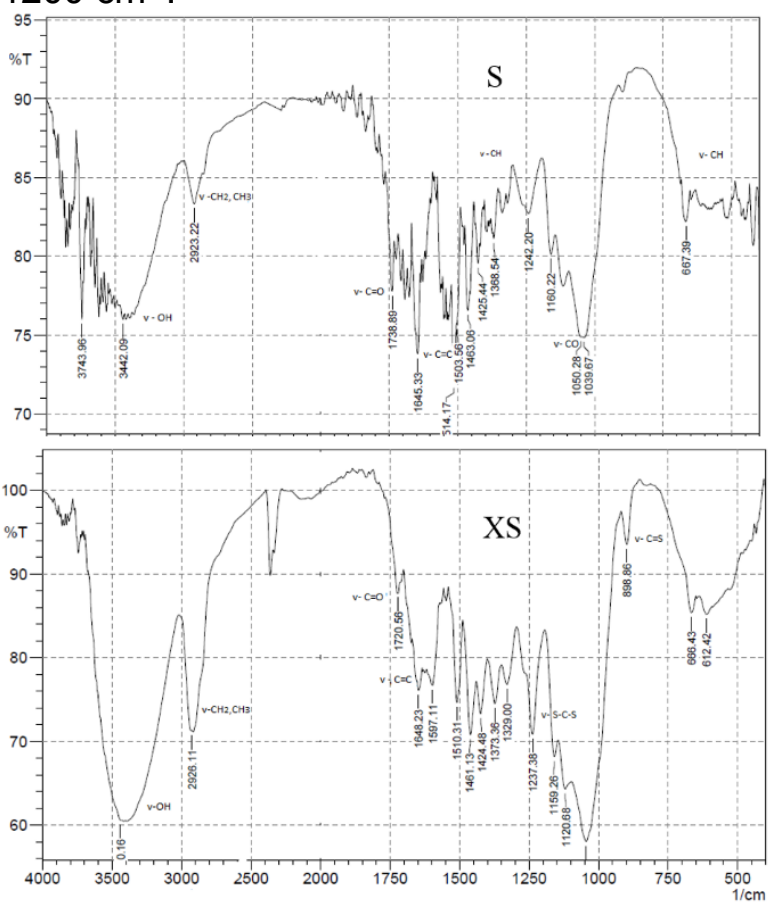

Figure 4. FTIR spectra of $S$ and XS

\section{CONCLUSION}

Xanthated sawdust has a great potential as an efficient adsorbent for heavy metals. Its adsorption capacity was $72 \mathrm{mg} \mathrm{Pb}^{2+} \mathrm{g}^{-1}$, following the Freundlich isotherm. The optimal $\mathrm{pH}$ for adsorption was $\geq 5$ with $90 \%$ adsorption and equilibrium was reached in about 120 minutes following a pseudo-second order kinetics.

\section{REFERENCES}

1. Acar, F.N.; Eren, Z. J. Hazard. Mater. 2006, 137, 909.

2. Chakraborty, S.; Tare, V. Bioresour. Technol. 2006, 97, 2407.

3. Jiang, Y.; Pang, H.; Liao, B. J. Hazard. Mater. 2009, 164, 1.

4. Kumar, A.; Rao, N.N.; Kaul, S.N. Bioresour. Technol. 2000, 71, 133.

5. Ho, Y.S. J. Hazard. Mater. 2006, 136, 681689.

6. Lagergren, S. K. Sven. Vetenskapsakad. Handl. 1898, 24, 1.

7. Liang, S.; Guo, X.; Tian, Q. Desalination. 2011, 275, 212.

8. Liang, S.; Guo, X.; Feng, N.; Tian, Q. J. Hazard. Mater. 2009, 170, 425.

9. Ho, Y.S; McKay, G. Proc. Biochem. 1999, 34, 451-465.

10. Memon, S.Q.; Memon, N.; Shah, S.W.; Khuhawar, M.Y.; Bhanger, M.I. J. Hazard. Mater. 2007, 139, 116.

11. Mustafa, S.; Hamid, A.; Naeem, A. Int. J. Miner. Process. 2004, 74, 317.

12. Ngah, W.W.; Hanafiah, M.A.K.M. Bioresour. Technol. 2008, 99, 3935.

13. Pagnanelli, F.; Mainelli, S.; Veglio, F.; Toro, L. Chem. Eng. Sci. 2003, 58, 20, 4709.

14. Panda, G.C.; Das, S.K.; Guha, A.K. Colloid Surf. $B$ 2008, 62, 173.

15. Patriota, S.N.; Cerutti, M.N.; Mulholland, D.S.; Marques, M.A.; Scheidt, G.N. J. Tche Chim. 2016, 13, 25, 37-42.

16. Pillai, S.S.; Deepa, B.; Abraham, E.; Girija, N.; Geetha, P.; Jacob, L.; Koshy, M. Ecotox. Environ. Safe. 2013, 98, 352.

17. Sciban, M.; Klasnja, M.; Skrbic, B. J. Hazard. Mater. 2006, 136, 266. 
18. Silgado, K.J.; Marrugo, G.D.; Puello, J. 20. Torres-Blancas, T.; Roa-Morales, G.; Fall, C.; Chem. Eng. Trans. 2014, 37, 721. Barrera-Díaz, C.; Ureña-Nuñez, F.; Pavón-Silva, 19. Taty-Costodes, V.C.; Fauduet, H.; Porte, C.; T.B. Fuel. 2013, 110, 4.

Delacroix, A. J. Hazard. Mater. 2003, 105, $121 . \quad$ 21. Tseng, R.L.; Wu, F.C.; Juang, R.S. J. Taiwan Inst. Chem. Eng. 2010, 41, 6, 661.

PERIÓDICO TCHÊ QUÍMICA • www.periodico.tchequimica.com • Vol. 14 N. 27.

- ISSN 1806-0374 (impresso) • ISSN 1806-9827 (CD-ROM) • ISSN 2179-0302 (meio eletrônico)

(C) 2017. Porto Alegre, RS. Brasil

The Periódico Tchê Quimica (ISSN: 1806-0374; 2179-0302) is an open-access journal since 2004. Journal DOI: 10.52571/PTQ. http://www.tchequimica.com. This text was introduced in this file in 2021 for compliance reasons.

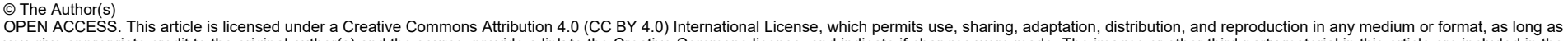
you give appropitate credit to the original author(s) and the source, provide a link to the Creative Commons license, and indicate if changes were made. The images or other third-party material in this article are included in the exceeds the permitted use, you will need to obtain permission directly from the copyright holder. To view a copy of this license, visit http://creativecommons.org/licenses/by/4.0/. 